\title{
MEDIA INVOLVEMENT AND COMMUNICATION STRATEGIES AND MECHANISMS OF THE EGYPTIAN MUSLIM BROTHERHOOD FROM 1928 TO 2015
}

\author{
Muhammad Chami*
}

\begin{abstract}
In this paper, we highlight the various communication resources used by the Egyptian Muslim Brotherhood (EMB) to recruit members or sympathizers. Based on the analysis, the media involvement and communication strategies and mechanisms used by the organization include a variety of traditional and available modern communication facilities. The goal of EMB's efforts is to convey its ideology to Egyptians and "to rebut the challenges of the adversaries" . In this regard, the author selects the following elements to be highlighted: (1) the publications' sections of EMB, (2) the vertical communication: The latter includes face-to-face meetings, group discussions, cassette recordings and the broadcasting channel that, the Brotherhood could use for propagating its agenda. The following section covers, (3) the conventional communication. The conventional communication presents the different publications served by the organization. This category covers periodic publications and books. The last section explains, (4) the use of information and communication technology (ICT).
\end{abstract}

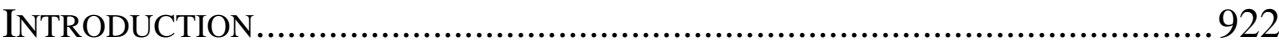

I. ThE BRotherhood’s PublicAtion SECTION.....................................923

II. VERTICAL COMMUNICATION OR INDOCTRINATION...............................925

III. CONVENTIONAL COMMUNICATION MECHANISMS OF THE BROTHERHOOD

(PUBLICATIONS) ....................................................................... 928

IV. THE USE OF THE INTERNET .....................................................931

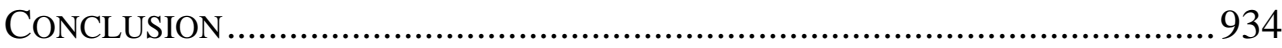

\section{INTRODUCTION}

In this paper, through selective secondary sources and further supportive materials from one of the leading scholars of the Brotherhood:

\footnotetext{
* A Multilingual of Arabic, English, French, Shikomori, and Japanese, Mohamed Chami Mkouboi from Comoros holds B.A. in Business Administration from Ritsumeikan Asia Pacific University (APU), a Master Degree in Comparative Studies of Politics and Administration in Asia at Kyushu University. He is currently writing his PhD dissertation in "the Recruiting Strategies of the Egyptian Muslim Brotherhood at Kyushu University, Japan. Potential subjects are Islamic Studies, International Politics, International Relations and Political Science. Potential Regions for his studies are East Asia, the Middle Eastern and the North African Regions.

${ }^{1}$ Richard P Mitchell, The Society of the Muslim Brothers 185 (New York: Oxford University Press, Inc., New York 10016-4314 1969).
} 


\section{MEDIA INVOLVEMENT AND COMMUNICATION 923}

Khalil al-Anani, the study identifies, categorizes and explains the different communication resources used by the Egyptian Muslim Brotherhood (EMB) to recruit as many Egyptians as possible to the organization during its long political history. Based on the study, the media involvement, and communication strategies and mechanisms used by the organization include a variety of all available communication means. The goal of EMB's efforts is to convey the message of the organization to the Egyptian society and "to rebut the challenges of the adversaries" ${ }^{2}$. In this regard, beside (1), the publications' sections of EMB, we identify what is called (2) the vertical communication: The latter includes face-to-face meetings, group discussions, cassette recordings and the broadcasting channel that, the Brotherhood could use for propagating its agenda. The following section covers (3) the conventional communication. The conventional communication highlights the different publications served by the organization. This category covers periodic publications ${ }^{3}$ and books. The last section explains (4) the use of the Internet and its media.

\section{THE BROTHERHOOD’s PUBLICATION SECTION}

Within the organizational structure of the Brotherhood, under the General Guidance Council, there are 10 divisions; two of them are the "Press \& Translation section" and the "Propagation of the Message section". However, according to Mitchell ${ }^{4}$, the Press \& Translation section became a special committee afterward. In the organizational structure of the Brotherhood, "committee" differs from "section", in the fact that, the latter is more important than "committee" in the real operation dynamism; this is because "the section" was "so intimately and directly involved in the orientation and training of members" . According to the latter scholar, "The press and translation committee concerns itself with (1) the publication of the Brothers' newspapers and magazines; (2) the collection and filing of all materials in all languages which related to the Brothers; and (3) the translation of all materials necessary for the interests of the message from and into Arabic"6. This paper assumes that, the other reason to shift "the press and translation" from "the section category" to "the committee

\footnotetext{
${ }^{2} I d$.

${ }^{3}$ Periodic publications: hard copies used for spreading EMB’s ideas periodically.

${ }^{4}$ Richard P Mitchell, The Society OF THE Muslim BRothers (New York: Oxford University Press, Inc., New York 10016-4314 1969).

${ }^{5}$ Richard P Mitchell, The Society of the Muslim Brothers 171 (New York: Oxford University Press, Inc., New York 10016-4314 1969).

${ }^{6}$ Id.
} 
category" is the cost of the latter in terms of human resources and money. Therefore, it has been taken out from the dynamic sections of the movement to be placed in the administrative machinery which is more technical than the functions of the sections. In the case of the role of the "Publication Section”, Mitchell quoted from the following document:

The publication' sections of the Organization are headed by "the Propagation of the Message section", it is also known as "the organization of the propaganda of the idea of the Brotherhood" by all means compatible with the spirit of Islam. This meant: (1) missionaries (Duaat in Arabic) for speeches and lectures, who were particularly well trained for public meetings (i.e., outside the Society); (2) publications of a scientific, cultural, and athletic, nature, none of which might be issued by any individual Brother without the authorization of the section; (3) guidance-spiritual, mental, and physical of each Brother towards an Islamic preparation by means of lectures, publications, and organized athletic activity. The section was responsible for supplying the branches with speakers and lecturers. It was also to provide every provincial division with a unified schedule of study for the missionary school which each of them was to maintain, the successful graduates of which would be elevated to the level of organizational missionaries (LD: AlLauha al-dakhiliyya al-Ammali'l-Ikhwan al-Muslimin 58-62: 22-37.

The above quoted paragraph might be interpreted into four main remarks: (1) The Brotherhood's inner circle tried to train their assigned members to propagate the mission of the organization. (2) The Brotherhood is strict and a closed organization in a way that members have no right to express themselves about the ideology that they believe without being assigned by special committee. This number (2) remark has been interpreted with other possible reasons by the former British Prime Minister, Tony Blair (1997-2007) in 2012; in his article, Blair believes that, it is completely wrong to consider the EMB as a normal political party. He argues that, in America as a single example, if anybody wants to join the Democratic or Republican Party, he can easily join and be welcomed. Nevertheless, to be a member of the Brotherhood, the candidate must be brainwashed during seven years before being accepted as an ordinary member ${ }^{8}$. Similarly, even if you are a member, you are not allowed to propagate the ideology of the organization without being assigned by the specialized committee. (3) The idea of providing a unified schedule to be distributed to all branches shows

\footnotetext{
${ }^{7}$ The author of this particular paper tries to get into the original source of this paragraph. However, he could not find the Arabic version. Therefore, it might be essential to refer to the second author: (Mitchell 1969, 171-2). Mitchell's book has been considered among the most authentic books reporting about the Brotherhood's activities.

${ }^{8}$ Egypt Sentences Al Jazeera Journalist, (2014). Available at http://www.aljazeera.com/pressoffice/2014/10/al-jazeera-journalist-sentenced-egypt20141014104613955831.html (last visited February 17, 2015).
} 


\section{MEDIA INVOLVEMENT AND COMMUNICATION 925}

that, the organization controls its ideological belief from up-down and never be from the other way around. Regardless of the negative impact of this strict federation system, many scholars stated that, this organizational structure plays a major role for the Brotherhood's communication efficiency. (4) The organization does not prohibit its members from recruiting or conveying the message of the organization. The abovementioned paragraph only prohibits preaching without being officially authorized by the assigned section or committee.

\section{VERTICAL COMMUNICATION OR INDOCTRINATION}

One of the most important goals of any political, social or religious movement is to enlarge its membership. In this regard, the Brotherhood's primary goal during its first three years after its inception on March, 1928 was the enlargement of its membership ${ }^{9}$. The process of recruitment might be pursued through several ways depending on a variety of circumstances related to the cultural, political and sociological aspects in any given country. In the case of Egypt, the face-to-face meeting is a driving force for the mobilization process. As a social and political actor, the Brotherhood used the same strategy as Anita Breuer mentioned, "Alongside its public works, the group relied on a strategy of vertical word of mouth communication" ${ }^{\prime \prime}$. In addition, group discussions, seminars and lectures in mosques, Islamic centres and other places played a great role for the organization to reach many Egyptians. In the case of the custom of using mosques for political and social motives, Islamic organizations prefer to have their own mosques in order to avoid any disturbance from a third party such as the Mosque owner or the authority ${ }^{11}$. This latter reason inspired the organization to think about having its own mosques, centres, schools and so forth.

Due to its evolution, the Brotherhood possessed its own building, composed of a mosque, school for boys, club and school for girls from $1930^{12}$. Nerveless, through its well-trained preachers, the Brotherhood could

\footnotetext{
${ }^{9}$ Richard P Mitchell, The Society OF THE Muslim Brothers 9 (New York: Oxford University Press, Inc., New York 10016-4314 1969).

${ }^{10}$ Breuer Anita, Media Experiences and Communication Strategies of the Egyptian Muslim Brotherhood from 1928 to 2011: A Brief Historical Overview, ForsCHUNGS Journal SOzIALE BEWEGUNGEN-PLUS 1 (Germany: Erhältlichunter 2014). Available at http://www.forschungsjournal.de/fjsb-plus (last visited February 2, 2015).

${ }^{11}$ In Egypt and many other Arab countries, the authority nowadays assigned the preachers who do mainly the do the Friday' sermons besides administrating the Mosques' affairs. One of the reasons is to be sure that, the mosques would be under the governing system.

${ }^{12}$ Richard P Mitchell, The SOCiETy OF THE Muslim BROTHERs 9 (New York: Oxford University Press, Inc., New York 10016-4314 1969).
} 
still have the opportunity to be the preferred preachers in many mosques in Egypt as independent preachers. In Muslim countries, "Mosques give the speakers the legitimacy and respectability they needed" ${ }^{13}$. Beside mosques and Islamic centres, the organization pursued its direct communication strategies through private spots. Richard Mitchell noticed, direct communication with the people in their homes, at their work, and in their places of leisure added to that legitimacy the quality of sincerity and the personal touch. In four years, these direct communication strategies resulted branches along the eastern edge of the Delta in Isma 'iliyya, Port Sa 'id, Suez, and abu-Suwayr, and on the western edge as far as SubraKhit; there was also minor contact with Cairo ${ }^{14}$.

During the Monarchy era, under the British control, the Brotherhood's preachers recorded and distributed cassette recordings through Egypt. The cassette recordings with very selective and touching topics were mainly distributed in the countryside and far away areas even beyond Egypt. This strategy of using cassette recordings continues to play a great role until the early 1970s. One of the famous preachers who served a lot of the cassette recordings' mechanisms was a blind Sheik named, Abdel Hamid Kishk ${ }^{15}$. In his autobiography, it has been stated, "In a few years, Kishk was the most popular preacher in the Arab world. For Friday sermons, attendance at his Mosque reached 10,000 by the early 1980s. Due to his fearless criticism of the ruling class, he was again arrested in 1981 as part of a crackdown on political opponents, but was released in 1982"16. This is because from Jamal Abdel Nasser regime, "the mosque constitutes the group's most important resource for members' recruitment and communication. Except for sport events, mosques were the only place where the public assembly of a large number of people was tolerated by the government. Specifically, Islamic message was thus crucial for the group's ability to use the mosque in order to disseminate an ideology that was critical of the regime" ${ }^{\prime 7}$. The preacher Kishk was in prison when Anwar Sadat, the Egyptian president at the time, was killed. It has been stated in the same article, that his tapes on 2000

\footnotetext{
${ }^{13} I d$.

${ }^{14} \mathrm{Id}$.

${ }^{15}$ Kishk' sermons were most of the time criticizing all Arab leaders in his time including Jamal Abdel Nasser, Sadat, Kdhafi, Hafidhal-Asad; but also, the Western interference in the Arab world affairs. Arab youth liked such topics and often considered a preacher like Kishk as a brave man.

${ }^{16}$ Islamic Encyclopaedia, (1986). Abd AL Hamid Kishk, (1933-1996CE). Available at http://islamicencyclopedia.org/public/index/topicDetail/id/14 (last visited February 17, 2015).

${ }^{17}$ Breuer Anita, Media Experiences and Communication Strategies of the Egyptian Muslim Brotherhood from 1928 to 2011: A Brief Historical Overview, ForsCHUngs JouRnal SozIALE BEWEGUNGEN-PLUS 3 (Germany: Erhältlichunter 2014). Available at http://www.forschungsjournal.de/fjsb-plus (last visited February 2, 2015).
} 


\section{MEDIA INVOLVEMENT AND COMMUNICATION 927}

topics were sold all over the Arab world in hundreds of thousands ${ }^{18}$.

Regarding the use of TV broadcasting mechanism, no literature showed any practice of this strategy along the Brotherhood's history until the new emergence of the Doha-based broadcaster: Aljazeera. The Satellite channel started broadcasting on November 1, 1996 founded by the new Qatari leader Hamad Bin Khalifa Al Thani who took power on June, $1995^{19}$. According to Mohammed El-nawawy, "Aljazeera's programming makes more sense to the Arab communities than any Western network" 20 . Aljazeera media network includes "Jazeera Satellite channel, several outlets, including the Internet and especially TV channels in multiple languages. The channel is accessible in several world regions. In 2005, Myers Joanne, the co-author of a book titled "Aljazeera", claims that, the latter channel accounted for a global audience of 35 million Arabic-speaking viewers”,21. As a controversial channel for many observers, Aljazeera became the most influential and effective broadcasting for the Brotherhood's active members and sympathizers to spread their political ideology to mainly the Arab World. The Brotherhood's approach toward Aljazeera broadcasting varies according to the given opportunity for broadcasting their performance in debating, lecturing and presenting about domestic and regional themes compared to other Egyptian and regional political opponents.

In a programme called "Al-Ittijah Al-Muakis" (the opposite direction), "similar to the CNN crossfire, this programme is known as the most popular and controversial 'talk show' in the Middle East" ${ }^{\text {"23 }}$, Brotherhood's members or sympathizers use the given opportunity to fire the Hosni Mubarak regime's authority and the current Abdel al-Fattah Sisi's regime authority. The latter regime which suspected the Satellite channel to make propaganda on behalf of the Brotherhood had imprisoned three journalists of the English

\footnotetext{
${ }^{18}$ Islamic Encyclopaedia, (1986). Abd AL Hamid Kishk, (1933-1996CE). Available at http://islamicencyclopedia.org/public/index/topicDetail/id/14 (last visited February 17, 2015).

${ }^{19}$ Bahry Louay, The New Arab Media Phenomenon: Qatar's Al-Jazera, VIII(2) MiddLE East Policy (2001). Available at http://onlinelibrary.wiley.com/doi/10.1111/1475-4967.00020/pdf (last visited June, 2002).

${ }^{20}$ El-nawawy Mohammed \& Iskandar Abdel, Al Jazeera: How the Free Arab News Network Scooped the World and Changed the Middle East, 45 (U.S.A: Westview Press 2002). ISBN 0-8133-4017-9. Available at http://www.westviewpress.com (last visited February 2, 2015).

${ }^{21}$ El-nawawy Mohammed \& Iskandar Abdel, Al Jazeera: How the Free Arab News Network Scooped the World and Changed the Middle East, 34 (U.S.A: Westview Press 2002). ISBN 0-8133-4017-9. Available at http://www.westviewpress.com (last visited February 2, 2015).

${ }^{22}$ The author watched this broadcasting programme several times. However, it often ended up by personal attacks from which one or both antagonistic debaters angrily left the hall.

${ }^{23}$ El-nawawy Mohammed \& Iskandar Abdel, Al Jazeera: How the Free Arab News Network Scooped the World and Changed the Middle East, 45 (U.S.A: Westview Press 2002). ISBN 0-8133-4017-9. Available at http://www.westviewpress.com (last visited February 2, 2015).
} 
Al-jazeera channel but released all in February, 2015 after spending about 400 days in prison ${ }^{24}$. Another programme called "BilaHudud" (without borders) is more about inviting mainly regional political actors to have interview with a journalist called Ahmed Mansur. This programme gives opportunity to potential invitees to highlight their political or social role in the pastor actual time. The latter journalist who is apparently a Brotherhood' sympathizer "has been sentenced in absentia to fifteen years imprisonment by Cairo's criminal court on the charge of torturing a lawyer in Tahrir Square during the January, 25 Uprising in 2011. Aljazeera denies the charge against Mansour, which follows the sentencing of other Aljazeera journalists, including Baher Mohamed, Peter Greste and Mohamed Fahmy, in June, 2014,"25.

The war on Aljazeera from almost all Middle East authorities and from the Hosni Mubarak's and Abdel Fattah al-Sisi's regimes in particular is mainly because of its sympathetic coverage in favour of the Brotherhood. Overall, the most influential figure using Aljazeera against mainly the Egyptian authority is Yusuf al-Qaradawi, a former member of the Brotherhood in exile for 30 years until 2011. The latter Brotherhood's unofficial member who currently serves as the chief religious scholar of a website called "IslamOnline", gave weekly lectures in Al-Jazeera called "alSharī'awa al-Hayāh" (Shariah and Life) since November, 1996 ${ }^{26}$. Qaradawi is also the most famous Muslim scholar among others who openly supports the organization's ideology and agenda through his more than 120 books and published articles since the mid-1950s ${ }^{27}$.

\section{Conventional COMmUnication Mechanisms OF THE BRotherhoOD} (Publications)

This Section specifically presents and examines the newsletters, newspapers, journals, magazines and books used by the Egyptian Muslim Brotherhood to spread its social and political activities. "In 1932, the Brotherhood moved its centre from Ismailia to Cairo: It began publishing its

\footnotetext{
${ }^{24}$ Egypt Sentences Al Jazeera Journalist, (2015). Available at http://www.aljazeera.com/pressoffice/2014/10/al-jazeera-journalist-sentenced-egypt20141014104613955831.html (last visited February 17, 2015).

${ }^{25}$ Egypt Sentences Al Jazeera Journalist, (2014). Available at http://www.aljazeera.com/pressoffice/2014/10/al-jazeera-journalist-sentenced-egypt20141014104613955831.html (last visited February 17, 2015).

${ }^{26}$ The 10th Anniversary of the Programm: "al-Shariawa al-Hayāh" (Shariah and Life), Available at http://www.aljazeera.net/programs/religionandlife/2006/11/8/ (last visited January 5, 2015)..

${ }^{27}$ Tamam Husam, Al-Qaradawi: Reading from the Controversial Issue of the Sheik and the Movement, (2011). Available at http://www.masress.com/shorouk/599400.
} 


\section{MEDIA INVOLVEMENT AND COMMUNICATION 929}

first weekly newsletter by 1938 , it had three hundred offices throughout the country and an estimated membership between 50,000 and $150,000^{28}$. The reason behind initiating the publication's strategies might be the rigorous use of the same strategies by the secular political and social movements in Egypt. In that period, the anti-religious movement in the social, academic and government institutions was strong among the Egyptian political elite. Mitchell stated, "The secularist and libertarian literary and social salons, societies, and parties; and the books, newspapers, and magazines which propagated those ideas whose sole goal was the weakening of the influence of religion" ${ }^{2930}$. In that period, Egypt was influenced by the Turkish Kamalist Revolution of 1924. Anti-Kamalist movement, the Brotherhood, contraattacked the secularism through its traditional face-to-face communication strategies, but they failed to gain the Egyptian society already influenced by the British life style as well. Nevertheless, the organization increased its publication activities both in quality and quantity. In this regard, Munson states, "At the same time, its newsletters became highly critical of the existing political regime in Egypt, especially the quasi-colonial British control of the country. The society produced several new publications over the next two years and increased the frequency of its public rallies"31.

In accordance with the use of conventional communication techniques, Mitchell quoted from Al-Dawat Waddaiyat, stating that, in the 1950s, "the unofficial but authoritative journal Majallat al-Da'wa (1951-1956) is useful” ${ }^{32}$. Within all Egyptian authorities, the ban or the relief of the Brotherhood's publications depend on the degree of criticism the organization engaged itself in, against the respective authorities. During Sadat's regime, "In 1976, the group was allowed to publish its monthly magazine, al'Dawa whose circulation is estimated to have reached 100,000 "3334. The reason is that, the Brotherhood avoided openly criticizing

\footnotetext{
${ }^{28}$ Munson Ziad, Islamic Mobilization: Social Movement Theory and the Egyptian Muslim Brotherhood, (U.S.A: University of California Press 2001).

${ }^{29}$ The content of this quotation was the main source of the EMB's founder's determination towards the organization's struggle for Islamizing the society. Contributing to the decline of religious influence and the evolution of secularism, Hassan al-Banna energetically decided to resist the secular movement.

${ }^{30}$ Richard P Mitchell, The Society of the Muslim Brothers 4 (New York: Oxford University Press, Inc., New York 10016-4314 1969).

${ }^{31}$ Munson Ziad, Islamic Mobilization: Social Movement Theory and the Egyptian Muslim Brotherhood, 488-489 (U.S.A: University of California Press 2001).

${ }^{32}$ Richard P Mitchell, The Society of the Muslim Brothers 1 (New York: Oxford University Press, Inc., New York 10016-4314 1969).

${ }^{33}$ Kepel Gilles, Le Prophète et Pharaon: Les Mouvements Islamistes Dansl Egypte Contemporaine, (Paris: La Découverte 1984).

${ }^{34}$ Wickham Carrie R., Mobilizing Islam: Religion, Activism and Political Change in Egypt, (New York: Columbia University Press 2002).
} 
the government. Nevertheless, the criticism was directed against Israel and supported the Palestinian resistance at the same time. Anita Breuer mentioned that, writers of the magazine decidedly rejected Israel as a state, both on political and religious grounds ${ }^{35}$. Consequently, when Sadat signed the peace accords with Israel at Camp David in 1979, the Brotherhood's relations with the regime quickly deteriorated and the magazine was prohibited again in $1981^{3637}$. As an experienced organization, whenever the governments blocked a particular activity like the prohibition of al'Dawa magazine, the Brotherhood often finds an alternative. "During this period, books of prominent Ikhwan' (Brotherhood) scholars were available in many bookstores, and surprisingly, the Brotherhood could publish three monthly magazines: al-Mukhtar, al-I'tisam, and Liwa'al-islam.

"The latter, which has often been described as the successor to the popular Brotherhood magazine $a l-D a$ 'wa, reached its height of circulation in 1987 with 95,000 copies out of which a roughly 55,000 were sold inside Egypt"38. "In fact, the EMB's actual communications outreach may have been substantially bigger"39. According to Manar Hassan, the reason behind al-Da'wa and al-Itisam's popularity was the transformation of the political language used by its writers and editors: "The growth of their political language came in their two most widely read publications, $a l-D a$ ' $w a$ and $a l$ 'Itisam, when the Brothers fought for a freedom of expression on the basis of a birth-right stipulated by Islam, exercised and guarded by the community of believers and not by a grant bestowed by the ruler" ${ }^{\prime 0}$. As far as the customers are concerned, contrary to what might be understood, buying magazines or books was often unaffordable to even the middle class, these publications were often xeroxed and distributed to a much larger

\footnotetext{
${ }^{35}$ Breuer Anita, Media Experiences and Communication Strategies of the Egyptian Muslim Brotherhood from 1928 to 2011: A Brief Historical Overview, ForsCHUNGS JouRnal SozIALE BEWEGUNGEN—PLUS 3 (Germany: Erhältlichunter 2014). Available at http://www.forschungsjournal.de/fjsb-plus (last visited February 2, 2015).

${ }^{36}$ In another published paper, the author of this paper mentioned that, the 1979 Camp David agreement was behind Sadat's assassination by an Islamist militant often connected to the Brotherhood by the organization's opponents. The Brotherhood denied the latter allegation.

${ }^{37}$ Breuer Anita, Media Experiences and Communication Strategies of the Egyptian Muslim Brotherhood from 1928 to 2011: A Brief Historical Overview, ForsCHUngs Journal SOzIALE BEWEGUNGEN-PLUS 3 (Germany: Erhältlichunter 2014). Available at http://www.forschungsjournal.de/fjsb-plus (last visited February 2, 2015).

${ }^{38} \mathrm{Id}$.

${ }^{39}$ Wickham Carrie R., Mobilizing Islam: Religion, Activism and Political Change in Egypt, (New York: Columbia University Press 2002).

${ }^{40}$ Hassan Manar, Outlawed and Outspoken: The Muslim Brotherhood in Pursuit of Legal Existence and Intellectual Development in Egypt, 7 (Middle Eastern Studies Dept. UC Berkeley 2005).
} 


\section{MEDIA INVOLVEMENT AND COMMUNICATION 931}

number by mainly the assigned publication' sections of the Brotherhood ${ }^{41}$. After Sadat's regime, Mubarak's regime could politically suppress the group in the beginning; however, with the emergence of the Internet, the organization efficiently used the newly technological mechanism for its political mobilization: Internet.

\section{THE USE OF THE INTERNET}

The intensive use of the Internet in Egypt started largely in 2000. Since then, Internet attracted particularly the Brotherhood's youth to master the different technical skills of the information communication technology. Based on statistical data, "One reason why the group could effectively use digital technology is Egypt's relatively young and technically versed population. The median age in Egypt is 24 and 33\% of the population is under 14. Cell phone use is wide spread with 67 mobile phone subscribers for every 100 inhabitants. About $10 \%$ of the population has used the Internet at least once" ${ }^{42}$. "Internet use is the highest among the country's young urbanites. Like other opposition forces, the Brotherhood benefited from the fact that Cairo and Alexandria are not only centres of cultural activities but also had reasonably well developed Internet infrastructures from 2000 onwards, thus enabling the cities' politically disaffected youth to create a dynamic public sphere online" ${ }^{43}$. Mastering the different technics of using Internet was not a big deal because "Egypt has long had an active online public sphere. Many of Egypt's political parties maintain websites and publish online newspapers. Even though the EMB was banned under the Mubarak regime, its website presence rivals if not superior to that of many legally permitted opposition parties”,4445.

This lately usage of the Internet has been initiated by the Egyptian secular political parties. In Mubarak's era, a nationalist party called Kifay

\footnotetext{
${ }^{41}$ Breuer Anita, Media Experiences and Communication Strategies of the Egyptian Muslim Brotherhood from 1928 to 2011: A Brief Historical Overview, ForsCHUNGS Journal SOZIALE BEWEGUNGEN_PLUS 4 (Germany: Erhältlichunter 2014). Available at http://www.forschungsjournal.de/fjsb-plus (last visited February 2, 2015).

${ }^{42}$ Howard Philip E. N., The Digital Origins of Dictatorship and Democracy, InFormation Technology and Political Islam (Oxford, New York: Oxford University Press 2011).

${ }^{43}$ Breuer Anita, Media Experiences and Communication Strategies of the Egyptian Muslim Brotherhood from 1928 to 2011: A Brief Historical Overview, FoRSCHUNGS JoURNAL SOZIALE BEWEGUNGEN-PLUS 4 (Germany: Erhältlichunter 2014). Available at http://www.forschungsjournal.de/fjsb-plus (last visited February 2, 2015).

${ }^{44}$ Even though, EMB was and is still banned by the authorities, through experiences and having active members outside the country, it is hard for the authorities to effectively block its activities.

${ }^{45}$ Howard Philip E. N., The Digital Origins of Dictatorship and Democracy, Information Technology and Political Islam (Oxford, New York: Oxford University Press 2011).
} 
was the main political actor in the period 2004-2005. Kifaya's leader, Ayman Nour is the first man to ever compete against former President Hosni Mubarak for the presidency of Egypt in 2005. Through his mobilization' success including the use of the Internet, he could mobilize many young Egyptians to support his nationalist movement. The majority of his supporters were activist blogging citizens. In this regard, All-Malky mentioned, "Activist blogging in Egypt had thus far been closely tied to the leftist Kifaya 'National Movement for Change', a grassroots movement agitating for civil rights and political reform since 2004" (All-Malky 2007) ${ }^{46}$. As EMB's members tended to support Kifaya as independent supporters, "Now, EMB bloggers sought to import the experience of secular bloggers into the Islamist camp and employ it to serve the Islamist movement ${ }^{47, "}$. This is to argue that, EMB's motivation to use the Internet was not mainly about challenging Mubarak's authoritarian regime in the beginning, rather than competing Kifaya and other social and political movements in the ground. Khalil Al-Anani, a field researcher of the Brotherhood stated, "The first phase of Brotherhood blogging can best be characterized as an attempt to challenge the secular domination of the Egyptian blogosphere" ${ }^{\text {48 }}$.

The starting point of using the Internet for the Brotherhood was the website in 2000. Khaled Hamza clearly mentioned in his article, "The year 2000 witnessed the Brotherhood's first serious web presence with the launch of several Arabic websites ${ }^{49,50}$. However, Philip Howard stated, "Initially, the EMB relied on bloggers who maintained servers located outside of the country and thereby couldn't be taken offline by the government $^{51}$. Hence, the study assumed that, the moderators of the EMB's online activities are outside Egypt. The reason is that, during the Mubarak and Sisi's regimes, members of the Brotherhood were and are still aware of how easy their online activities could and can be caught by the domestic

\footnotetext{
${ }^{46}$ All-Malky Rania, Blogging for Reform: The Case of Egypt, ARAB MEDIA \& SoCIETY (February 2007).

${ }^{47}$ Al-Anani Khalil, The Muslim Brotherhood in Egypt: The Aging Wrestles the Time, (Cairo, Egypt:

Al- Shuruk International Press 2007).

${ }^{48} I d$.

${ }^{49}$ Based on the author's investigation, the following Arabic website is the result of the combination of many others. This website is very rich in terms of information about the History of the Brotherhood and the updated information. Available at http://www.ikhwanonline.com/.

${ }^{50}$ Hamza Khaled, Faith and Media. Muslim Brotherhood's Media, from the Missionary to the Political discourse: Ikhwanweb as an Example, (Ikhwanweb 2009). Available at http://www.ikhwanweb.com/article.php?id=20546.

${ }^{51}$ Howard Philip E. N., The Digital Origins of Dictatorship and Democracy, Information TeChNology and Political Islam (Oxford, New York: Oxford University Press 2011).
} 


\section{MEDIA INVOLVEMENT AND COMMUNICATION 933}

secret security service agents. The presence of active members outside of the country helps the organization to arrange, analyse and propose new ideas in favour of the political ideology of the Brotherhood. In this respect, Breuer mentioned, "In essence, the analysis of web-features on ikhwanweb.com, the official English website of the Muslim Brotherhood, and fjponline.com ${ }^{52}$, the English website of the Brotherhood's political arm the Freedom and Justice Party, reveals that, these web presences mainly serve the functions of providing information and of fostering interaction and dialogue with users" $"$.

As the organization started to seriously consider the international community's role, especially the U.S toward pressuring Mubarak's regime in 2005, focusing on the Western opinion through English Website became necessary. Accordingly, "Khaled Hamza, the English website's chief editor, describes its mission as follows:

Ikhwanweb's basic mission is to bridge the knowledge gap between the MB and Western intellectuals so that they get to know its ideology without distortion, and understand our political, cultural, and moderate religious message...Ikhwanweb was not concerned with spreading Islam...We are rather adopting a political, cultural and intellectual discourse...Ikhwanweb's news coverage avoided any direct religious discourse...We worked hard to make the editing mainly based on press professionalism, objectivity and neutrality. We focused on issues of democracy, reform, political repression, torture and tyranny”, ${ }^{,}$.

As similar ambition to open up to Westerners, The Brotherhood started also to expose its ideology and history to all through their websites. "In 2010, the MB launched Ikhwanwiki $4^{55}$ : a mini library of about 1,700 articles that offers the Brotherhood's perspective of their own history and ideology" " "As Evgeny Morozov (2010) ${ }^{57}$ has pointed out, Wikis, with

\footnotetext{
${ }^{52}$ Available at http: ikhwanweb.com; fjponline.com.

${ }^{53}$ Breuer Anita, Media Experiences and Communication Strategies of the Egyptian Muslim Brotherhood from 1928 to 2011: A Brief Historical Overview, ForSCHUNGS JouRnAl SozIALE BEWEGUNGEN-PLUS 5 (Germany: Erhältlichunter 2014). Available at http://www.forschungsjournal.de/fjsb-plus (last visited February 2, 2015).

${ }^{54}$ Hamza Khaled, Faith and Media. Muslim Brotherhood's Media, from the Missionary to the Political discourse: Ikhwanweb as an Example, (Ikhwanweb 2009). Available at http://www.ikhwanweb.com/article.php?id=20546.

${ }^{55}$ The author found the web without " 4 " as it has been mentioned by Amer (2010). Available at http://www.ikhwanwiki.com/.

${ }^{56}$ Amer Pakinam, Muslim Brotherhood Use New Media to Document History, EgYPT INDEPENDENT (2010). Available at http://www.egyptindependent.com/news/muslim-brotherhood-use-newmediadocument-history.

${ }^{57}$ Evgeny Morozov' statement shows that, EMB has, in fact, many other wikis; however, the mentioned wiki website in this footnote is the main one.
} 
their open-editing philosophy poses a high risk of revealing intraorganizational tensions ${ }^{58}$. In case of the EMB, the Ikhwanwiki experiment may well backfire by making ideological splits between the movement's old guard and its younger Internet-savvy elements visible to the public"59. In one of the authors' papers, the author highlighted the different generations within the Brotherhood with their differences. Among these generations, there are "the bloggers. The latters are between 25 to 35 years old and are the most opened minded members compared with all other generations, due to the influences from outside Egypt. Consequently, this generation is politically marginalized inside the organization by the 1980s and 1990s generations. In order to reveal their opinions, the bloggers use twitter ${ }^{60}$, Facebook ${ }^{61}$ and so forth.

In the case of using Facebook, "Digital content produced by the EMB has also come to dominate Facebook, which is one of the most central nods in the Egyptian online network of political information"62. This Facebook's involvement was well described by many Middle East studies' scholars as one of the influential factors behind the mass protests that collapsed the regime of Hosni Mubarak on January 25, 2011 (Ramadan 2011) ${ }^{63}$. Since then, the Brotherhood' supporters using Facebook keep gradually increasing due to the brutality executed by the Egyptian authority that caused many active members to flee the country.

\section{CONCLUSION}

As a summary and discussion of this paper, the full paper is all about presenting and highlighting the different communication strategies and mechanisms served by the Egyptian Muslim Brotherhood to recruit the Egyptian people to the organization. However, in order to facilitate the readers, we present the findings of the study into four categories: First is the

\footnotetext{
${ }^{58}$ Evgeny Morozov' statement shows that EMB has, in fact, many other wikis; however, the mentioned wiki website in this footnote is the main one.

${ }^{59}$ Breuer Anita, Media Experiences and Communication Strategies of the Egyptian Muslim Brotherhood from 1928 to 2011: A Brief Historical Overview, FoRSCHUNGS JOURNAL SOZIALE BEWEGUNGEN-PLUS 5 (Germany: Erhältlichunter 2014). Available at http://www.forschungsjournal.de/fjsb-plus (last visited February 2, 2015).

${ }^{60}$ EMB's twitter's account used mainly by the youth. Available at https://twitter.com/Ikhwanweb.

${ }^{61}$ Facebook is mainly used by MB's youth too. Available at https://www.facebook.com/ElShaheed.

${ }^{62}$ Breuer Anita, Media Experiences and Communication Strategies of the Egyptian Muslim Brotherhood from 1928 to 2011: A Brief Historical Overview, FoRSCHUNGS JOURNAL SOZIALE BEWEGUNGEN-PLUS 6 (Germany: Erhältlichunter 2014). Available at http://www.forschungsjournal.de/fjsb-plus (last visited February 2, 2015).

${ }^{63}$ Ramadan T., L'Islam et le Reveil Arabe, Imprime en FranCAIS, N. D’IMPRESSION: 80989, DePOT LEGAL (Lyon, French: Presses du Chatelet 2011).
} 


\section{MEDIA INVOLVEMENT AND COMMUNICATION 935}

publications' section of EMB. This category was divided into two; "Translation and Press" section and "Propagation of the Message section". However, based on the evolution of the organization, "the Translation \& Press section" was separated from the second category and became a special committee due to its challenging and costly demands. The "Propagation of the Message section" took over the dynamism of the publication section. Second is "the vertical communication: This section includes face-to-face meetings, group discussions, cassette recordings and the broadcasting channel that the Brotherhood could use for propagating its agenda. Third is "the conventional communication". The conventional communication presents the different publications (hardcopies) served by the organization. This category covers periodic publications and books. Fourth is the use of the information and communication technology. However, further focused studies about the challenges and obstacles vis-à-vis the suppressive tactics used by the Egyptian military since the overthrow of the EMB's president from power on July 3, 2013 are needed. 